MINERALOGIA POLONICA

DOI 10.2478/v10002-007-0022-9

PL ISSN 0032-6267

Vol. 38, No 2, 2007

Irina GALUSKINA ${ }^{1}$, Evgeny GALUSKIN ${ }^{1}$, Roman WŁODYKA ${ }^{1}$, Piotr DZIERŻANOWSKI ${ }^{2}$, Roman WRZALIK ${ }^{3}$

\title{
ATOLL GARNETS IN “ACHTARANDITE” SERPENTINITES: MORPHOLOGY, COMPOSITION AND MODE OF ORIGIN
}

\author{
Received April 26, 2007; accepted November 14, 2007
}

Abstract. Atoll garnets in aposkarn serpentinite from the Wiluy River, Republic of Sakha-Yakutia, Russia, have the classic form comprising a garnet core, an intermediate zone filled with chlorite-group minerals and an outer garnet atoll. The core of an illustrated example is complexly zoned from schorlomite to grossular-andradite. Morphologically, the core is a rhombic dodecahedral crystal. The atoll crystallized as a tetragon-trisoctahedron with minor rhombic dodecahedron faces and is composed of hibschite and "hydroandradite". The atoll garnet formed as the result of selective dissolution and substitution by chlorite of an internal hibschite zone with columnar structure that became unstable under new conditions of crystallization. The pattern of dissolution traces defects in the garnet crystal. The growth of the atoll garnets reflects the main stages in the evolution of the Wiluy deposit itself and is associated with the development of the Siberian traps.

Key-words: atoll garnet, morphology, hibschite, Raman spectroscopy, serpentinite, Wiluy River, Russia

\section{INTRODUCTION}

Beginning twelve years ago, during work on "achtarandite" represented by hibschite pseudomorphs of wadalite (Galuskin et al. 1995; Galuskina et al. 1998), we encountered minerals of the hydrogarnet group for the first time. Searching the literature on hydrogarnet, we discovered the valuable early work on crystal chemistry of hydrogarnets published by Professor Witold Żabiński in 1965 (Żabiński 1965a, b). About that time, our friendship with Professor Żabiński began which ongoing common scientific interests connected with research on the minerals of the garnet and vesu-

1 University of Silesia, Faculty of Earth Sciences, ul. Będzińska 60, 41-200 Sosnowiec, Poland; e-mail: irina@wnoz.us.edu.pl.

2 Mineralogy and Petrology, Institute of Geochemistry, Al. Żwirki i Wigury 93, 02-089 Warszawa, Poland.

3 University of Silesia, Institute of Physics, ul. Uniwersytecka 4, 40-007 Katowice, Poland. 
vianite groups served to cement. In this paper devoted to his memory, we propose a mechanism for the formation of atoll garnets in the Wiluy River, Republic of Sakha-Yakutia, Russia.

Atoll structures are characteristic of minerals of both metamorphic and metasomatic origin. They are three-fold structures comprising an internal core, an intermediate zone and an external ring - the atoll. The core and the atoll typically involve the same mineral species whereas the intermediate zone is filled with a mineral of different composition or with a mixture of minerals. Atoll structures characterizing metamorphic garnets (Rast 1965; Atherton, Edmunds 1966; Cooper 1972; Smellie 1974; Ushakova, Usova 1990; Homam 2003; Cheng et al. 2007), hydrogarnets of metasomatic genesis (Galuskina et al. 1998), magnetite in skarns (Grigoriev, Zhabin 1975) and chromite-magnetite spinel from serpentinite (Galuskina et al. 2007a) have been described over the years. During our investigation of the atoll structure, primary consideration was given to establishing the relative crystallographic orientation of the atoll and the core - often impossible with optical observations of isotropic garnets. However, Electron Backscattered Diffraction (EBSD) and orientation contrast (OC) imaging contrast have been used with success in recent atoll garnet investigations (Homam 2003; Cheng et al. 2007).

\section{METHODS OF INVESTIGATION}

Our research on the morphology of the Wiluy atoll garnets, and the selection of samples for investigation by Raman spectroscopy, was carried out using a scanning electron microscope (Philips/FEI ESEM XL30) with EDS/EDAX under conditions of high and low (0.2-0.3 Torr) vacuum and an optical microscope (OLYMPUS).

Garnet chemical compositions were determined using a microprobe analyzer (CAMECA SX100, $15 \mathrm{kV}, 20 \mathrm{nA}$ electron beam). The analytical lines and standards used were $\mathrm{CaK} \alpha, \mathrm{SiK} \alpha, \mathrm{MgK} \alpha$ - diopside, $\mathrm{TiK} \alpha$ - rutile, $\mathrm{CrK} \alpha-\mathrm{Cr}_{2} \mathrm{O}_{3}, \mathrm{AlK} \alpha$ - orthoclase, $\mathrm{FeK} \alpha-\mathrm{Fe}_{2} \mathrm{O}_{3}, \mathrm{MnK} \alpha$ - rhodochrosite, $\mathrm{VK} \alpha-\mathrm{V}$, ZrL $\alpha$ - zircon, ScK $\alpha-\mathrm{Sc}$, $\mathrm{HfM} \alpha-\mathrm{HfO}_{2}$ and $\mathrm{YL} \alpha-\mathrm{Y}_{3} \mathrm{Al}_{5} \mathrm{O}_{12}$. Element-concentration corrections were calculated using a PAP procedure accepted by CAMECA.

Garnet Raman spectra were recorded using a LabRam System spectrometer (Jobin-Yvone-Horiba). It was equipped with a monochromator (1800 line/mm grating), a charge-coupled device comprising a Peltier-cooled detector $(1024 \times 256)$ and an Olympus BX40 confocal microscope. The incident laser excitation was provided by an air-cooled argon laser source operating at $514.5 \mathrm{~nm}$. The power at the exit of a 100x objective varied from $20-30 \mathrm{~mW}$. In order to avoid undesirable Rayleigh scattering, two notch-filters were used that cut the laser line at $200 \mathrm{~cm}^{-1}$. The non-polarized spectra were recorded in 0 degree geometry, in the $3000-3800 \mathrm{~cm}^{-1}$ range of Raman shift, and with a spectral resolution of $3.5 \mathrm{~cm}^{-1}$. The collection time was $30 \mathrm{~s}$ and six scans were accumulated. The Raman scattering line of a silicon plate $\left(520.7 \mathrm{~cm}^{-1}\right)$ was routinely used in the calibration of the monochromator. 


\section{GEOLOGICAL SETTING}

The Wiluy deposit is confined to a gigantic, metasomatically-altered, siliceous-carbonate xenolith of Ordovician sedimentary rocks enclosed within a large gabbro-dolerite layered intrusion of Triassic age related to the Siberian traps (Oleinikov 1979). The deposit, comprising aposkarn rocks - serpentinites and rodingite-like rocks (Galuskin 2005), is the type location for grossular and wiluite (Groat et al. 1998) and for hibschite pseudomorphs "achtarandite" (Lyakhovich 1952; Galuskin et al. 1995). The area of our investigations is located at the middle reach of the Wiluy River, some $8 \mathrm{~km}$ from the town of Chernyshevsky in the Republic of Sakha-Yakutia, Russia. Atoll garnets 1-3 mm in size were first noted in the Wiluy deposit by V.V. Lyakhovich (1954), he termed them "ring garnets".

The groundmass of the rock containing the atoll garnets comprises a finely-crystalline mixture of serpentine, chlorite and hydrogarnet. The serpentine is mainly lizardite, the chlorite is clinochlore and the hydrogarnet belongs to the hibschite-"hydroandradite" series. Large $(2.5-3 \mathrm{~cm})$ dark green metacrystals of wiluite-vesuvianite and equally large, light green-gray pseudomorphs of "achtarandite" with well-preserved tetrahedral forms characterize the rock. "Achtarandite" with a hydrogarnet skeleton serves to concentrate hibschite in micro-rodingite spots in the serpentinite. Chlorite is irregularly dispersed in the rock. Relics of fassaitic pyroxene are common within the chlorite. Accessory minerals include perovskite, magnesiochromite, baddeleyite, anatase, titanite, pyrite, hematite, goethite and oxide-hydroxides of manganese and a potentially new manganese analog $\left(\mathrm{MnTi}_{2} \mathrm{O}_{4}(\mathrm{OH})_{2}\right)$ of kassite (Galuskin et al. 2004; Galuskin 2005).

\section{MORPHOLOGY AND CHEMICAL COMPOSITION OF THE WILUY ATOLL GARNETS}

Garnets from the serpentinites of the Wiluy deposit display a classic atoll structure a core separated by an intermediate zone from an outer ring or atoll (Fig. 1a, b). Wiluite-vesuvianite crystals with incomplete atoll structures occur together with atoll garnets (Fig. 1a). In the example shown in Figure 1b, the garnet core is a rhombododecahedral crystal. The external form of this atoll garnet is a tetragon-trisoctahedron with minor development of rhombic dodecohedron faces (Fig. 1a, b). The intermediate zone is filled with fine-grained, flake-like aggregates of chlorite (Fig. 1c). The outer atoll has an inhomogeneous structure. An external massive part and an internal part with columnar structure can be distinguished. The internal surface of the atoll displays dissolution forms inheriting growth defects in the crystal (Fig. 1d-f). Dissolution holes have crystallographic shapes reflecting the two-dimensional symmetry of the face (Fig. 1f).

The central crystal of the atoll garnet shows a complicated chemical zonation in which three main zones can be distinguished (zones I-III, Table 1). These zones are well seen on BSE images and X-ray maps (Fig. 2, Table 1). On an early schorlomite-Al-Ti 

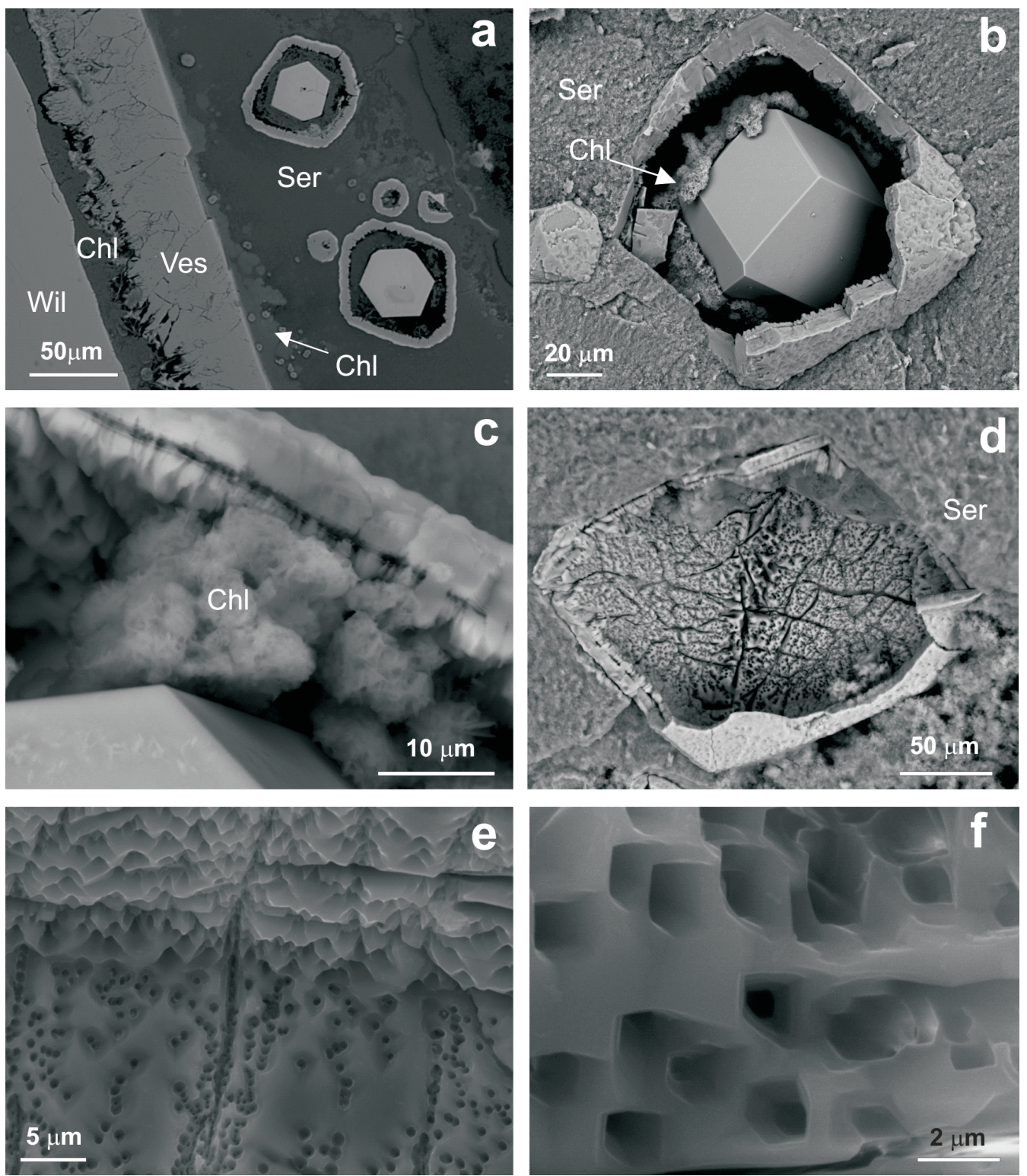

Fig. 1. Morphology of atoll garnets: a - garnets with the full atoll structure composed of the core, the intermediate zone and the atoll. The cores comprise idiomorphic garnet crystals of rhombic dodecahedral form. Atoll garnets are a combination of dominant tetragon-trisoctahedron and subordinate rhombic dodecahedral forms. Nearby is a large atoll crystal of vesuvianite-wiluite (left side of the photo);

$\mathrm{b}$ - common view of atoll garnet on fresh chip; $\mathrm{c}$ - magnified detail of the intermediate zone

(filled with flake-like aggregates of chlorite) and the atoll zone; $\mathrm{d}$-internal surface of the atoll with linear and point dissolution forms visible on the surface of the columnar zone; e - detail of the internal structure of a columnar zone; $\mathrm{f}$ - dissolution holes inheriting symmetry of the face.

Abbreviations: Chl - chlorite, Ser - serpentine, Ves - vesuvianite, Wil - wiluite 

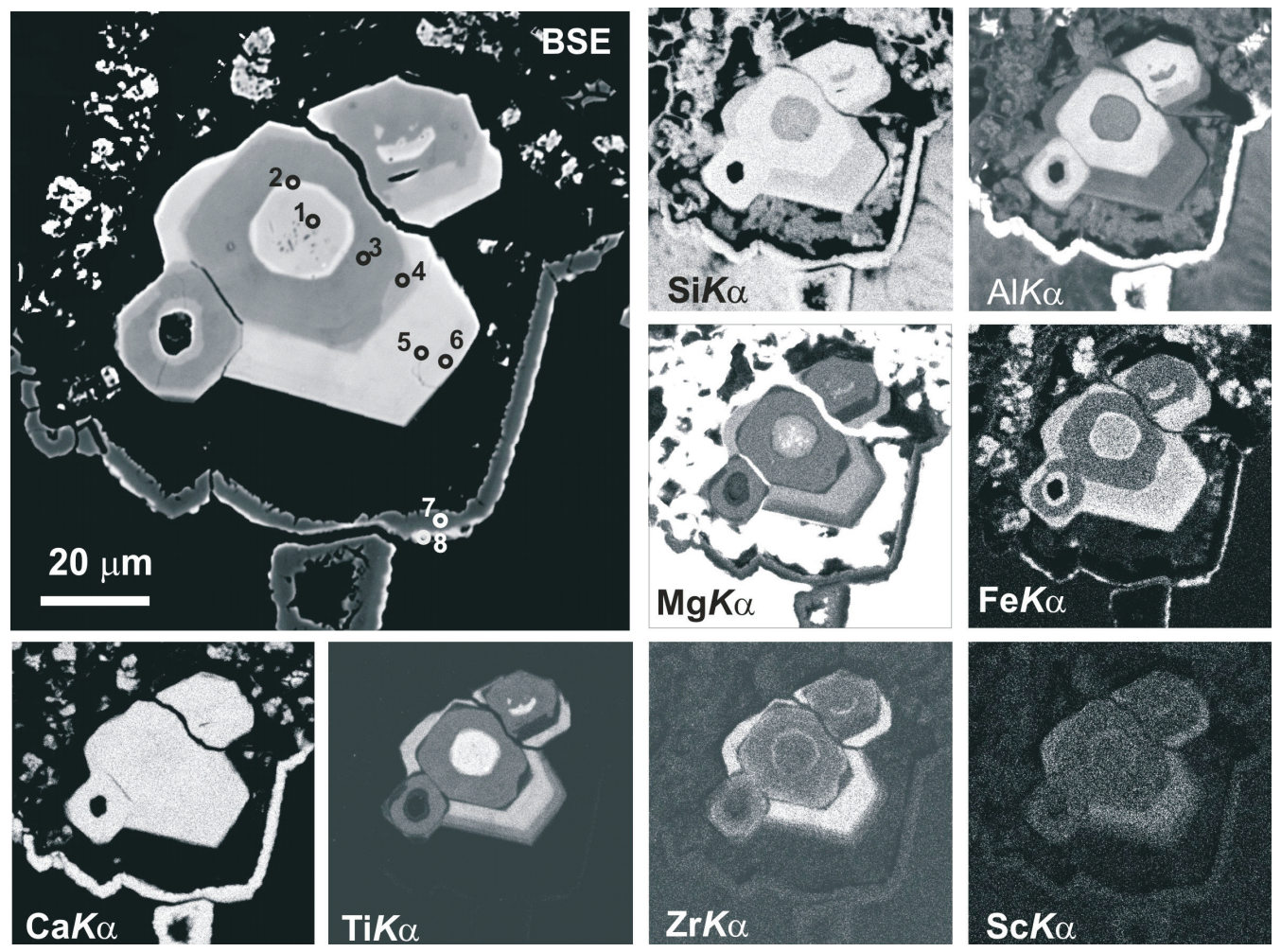

Fig. 2. BSE image and X-ray maps of selected elements in a garnet crystal. 1-8 - points of analyses are given in Table 1

zone (zone $\mathrm{Ia})$, a thin reaction zone $(\mathrm{Ib})$ of andradite-Ti-Al is evident (Fig. 2, Table 1). A zone of grossular-Fe-Ti (IIa) regenerated by a thin andradite-Al zone (IIb) follows. A zone of Zr-bearing andradite-schorlomite-Al (IIIa) grows on zone II. Variations in Sc content characterize this IIIa zone (Fig. 2, Table 1). The outermost zone (IIIb) of the core garnet is a more ferrous garnet with $57.5 \%$ of the andradite molecule (Fig. 2, Table 1).

The atoll is formed of hibschite (zone IV) with a thin outer zone of "hydroandradite" (Fig. 2, Table 1). The anomalous anisotropy displayed by the grossular zones of the core (IIa) and atoll (IV) of the atoll garnet demonstrate that the core and atoll have the same crystallographic orientation.

A Raman spectroscopy investigation was used to confirm the presence of $(\mathrm{OH})$ groups in the composition of the garnet atoll - with calculation on the basis of charge balance (Table 1, Fig. 3). For the investigated hydrogarnets, internal O-H stretching modes in the range of 3000-3800 cm that derive from the $\mathrm{O}_{4} \mathrm{H}_{4}$ groups can be observed in the unpolarized Raman spectra at room temperature (Fig. 3). The O-H stretching region consists of two $\mathrm{O}-\mathrm{H}$ band sub-regions centered around 3670 and $3600 \mathrm{~cm}^{-1}$. The $3670 \mathrm{~cm}^{-1}$ band is connected with vibrations of $\mathrm{O}_{4} \mathrm{H}_{4}$ groups that are surrounded by other $\mathrm{O}_{4} \mathrm{H}_{4}$ groups and the $3600 \mathrm{~cm}^{-1}$ band to $\mathrm{O}_{4} \mathrm{H}_{4}$ clusters adjacent to their $\mathrm{SiO}_{4}$ neighbours (Rossman, Aines 1991). As is clear from Figure 3, the band envelope can fit 
TABLE 1

Analytical data for atoll garnet zones. Points of analyses are as in Fig. 2

\begin{tabular}{|c|c|c|c|c|c|c|c|c|}
\hline$x$ & $\begin{array}{c}1 \\
\text { Ia }\end{array}$ & $\begin{array}{c}2 \\
\mathrm{Ib}\end{array}$ & $\begin{array}{c}3 \\
\text { II }\end{array}$ & $\begin{array}{c}4 \\
\mathrm{IIb}\end{array}$ & $\begin{array}{c}5 \\
\text { IIIa }\end{array}$ & $\begin{array}{c}6 \\
\text { IIIb }\end{array}$ & $\begin{array}{c}7 \\
\text { IV }\end{array}$ & $\begin{array}{l}8 \\
V\end{array}$ \\
\hline $\mathrm{SiO}_{2}$ & 30.60 & 31.14 & 36.10 & 36.63 & 32.07 & 33.95 & 36.58 & 36.18 \\
\hline $\mathrm{TiO}_{2}$ & 11.89 & 8.19 & 4.25 & 1.29 & 9.16 & 4.46 & 0.17 & 0.22 \\
\hline $\mathrm{ZrO}_{2}$ & 0.19 & 0.41 & 0.14 & n.d. & 1.67 & 0.19 & n.d. & n.d. \\
\hline $\mathrm{HfO}_{2}$ & 0.12 & 0.13 & 0.04 & n.d. & 0.11 & 0.04 & n.d. & n.d. \\
\hline $\mathrm{Al}_{2} \mathrm{O}_{3}$ & 6.74 & 5.39 & 12.38 & 8.81 & 4.46 & 4.84 & 19.67 & 6.97 \\
\hline $\mathrm{Sc}_{2} \mathrm{O}_{3}$ & n.d. & n.d. & n.d. & n.d. & 0.09 & n.d. & n.d. & n.d. \\
\hline $\mathrm{Cr}_{2} \mathrm{O}_{3}$ & 0.10 & 0.72 & 1.90 & 0.07 & 1.04 & 0.44 & n.d. & 0.03 \\
\hline $\mathrm{Y}_{2} \mathrm{O}_{3}$ & 0.02 & 0.12 & n.d. & 0.02 & 0.05 & 0.08 & 0.03 & n.d. \\
\hline $\mathrm{V}_{2} \mathrm{O}_{3}$ & 0.14 & 0.12 & 0.08 & 0.05 & 0.18 & n.d. & n.d. & 0.03 \\
\hline $\mathrm{Fe}_{2} \mathrm{O}_{3}{ }^{*}$ & 13.37 & 18.74 & 8.35 & 17.56 & 15.11 & 20.44 & 3.65 & 21.96 \\
\hline $\mathrm{FeO}^{*}$ & 0.59 & 0.44 & & & & & & \\
\hline $\mathrm{MnO}$ & 0.13 & 0.03 & 0.03 & 0.13 & 0.15 & 0.01 & 0.06 & 0.18 \\
\hline $\mathrm{MgO}$ & 2.15 & 0.94 & 1.16 & 0.56 & 1.90 & 0.90 & 0.46 & 0.70 \\
\hline $\mathrm{CaO}$ & 33.64 & 33.51 & 35.33 & 35.02 & 34.38 & 34.35 & 37.67 & 34.52 \\
\hline $\mathrm{H}_{2} \mathrm{O}^{* *}$ & & & & 0.41 & 0.48 & 0.60 & 2.34 & 0.98 \\
\hline Total & 99.68 & 99.88 & 99.76 & 100.55 & 100.85 & 100.30 & 100.63 & 101.77 \\
\hline \multicolumn{9}{|c|}{ Crystal chemical formula } \\
\hline $\mathrm{Ca}$ & 2.95 & 2.98 & 2.99 & 2.99 & 2.99 & 3.00 & 3.00 & 2.93 \\
\hline $\mathrm{Mn}^{+2}$ & 0.01 & & & 0.01 & 0.01 & & & 0.01 \\
\hline $\mathrm{Mg}$ & 0.04 & 0.01 & 0.01 & & & & & 0.06 \\
\hline $\mathrm{Y}$ & & 0.01 & & & & & & \\
\hline$\Sigma \mathbf{X}$ & 3 & 3 & 3 & 3 & 3 & 3 & 3 & 3 \\
\hline $\mathrm{Ti}^{+4}$ & 0.73 & 0.51 & 0.25 & 0.08 & 0.56 & 0.27 & 0.01 & 0.01 \\
\hline $\mathrm{Zr}$ & 0.01 & 0.02 & 0.01 & & 0.07 & 0.01 & & \\
\hline $\mathrm{V}^{+3}$ & 0.01 & 0.01 & & & 0.01 & & & \\
\hline $\mathrm{Al}$ & 0.65 & 0.53 & 1.15 & 0.83 & 0.43 & 0.47 & 1.73 & 0.65 \\
\hline Sc & & & & & 0.01 & & & \\
\hline $\mathrm{Cr}^{+3}$ & 0.01 & 0.04 & 0.11 & & 0.07 & 0.03 & & \\
\hline $\mathrm{Fe}^{+3}$ & 0.33 & 0.75 & 0.33 & 1.02 & 0.62 & 1.11 & 0.21 & 1.31 \\
\hline $\mathrm{Fe}^{+2}$ & 0.04 & 0.03 & & & & & & \\
\hline $\mathrm{Mg}$ & 0.22 & 0.11 & 0.13 & 0.07 & 0.23 & 0.11 & 0.05 & 0.03 \\
\hline$\Sigma \mathbf{Y}$ & 2 & 2 & 2 & 2 & 2 & 2 & 2 & 2 \\
\hline $\mathrm{Si}$ & 2.51 & 2.58 & 2.85 & 2.92 & 2.61 & 2.77 & 2.72 & 2.87 \\
\hline $\mathrm{Fe}^{+3}$ & 0.49 & 0.42 & 0.15 & 0.03 & 0.30 & 0.14 & & \\
\hline$\Sigma \mathbf{Z}$ & 3 & 3 & 3 & 2.95 & 2.91 & 2.91 & 2.72 & 2.87 \\
\hline $\mathrm{OH}$ & & & & 0.22 & 0.26 & 0.33 & 1.16 & 0.54 \\
\hline Grs & 32.5 & 26.5 & 57.5 & 41.5 & 21.5 & 23 & 86.9 & 32.7 \\
\hline Adr & 17.5 & 40.5 & 22 & 51 & 39.5 & 57.5 & 10.1 & 65.8 \\
\hline Ti-grt & 50 & 33 & 20.5 & 7.5 & 39 & 19.5 & 3 & 1.5 \\
\hline
\end{tabular}

x - analyses 1-3 calculated per 8 cations, 4-6 - normalized per $3 \mathrm{Ca}, 7-8$ - calculated per 5 cations.

* $-\mathrm{FeO}$ and $\mathrm{Fe}_{2} \mathrm{O}_{3}$ calculated by valence balance.

** $-\mathrm{H}_{2} \mathrm{O}$ calculated by valence balance.

n.d. - not determined. 


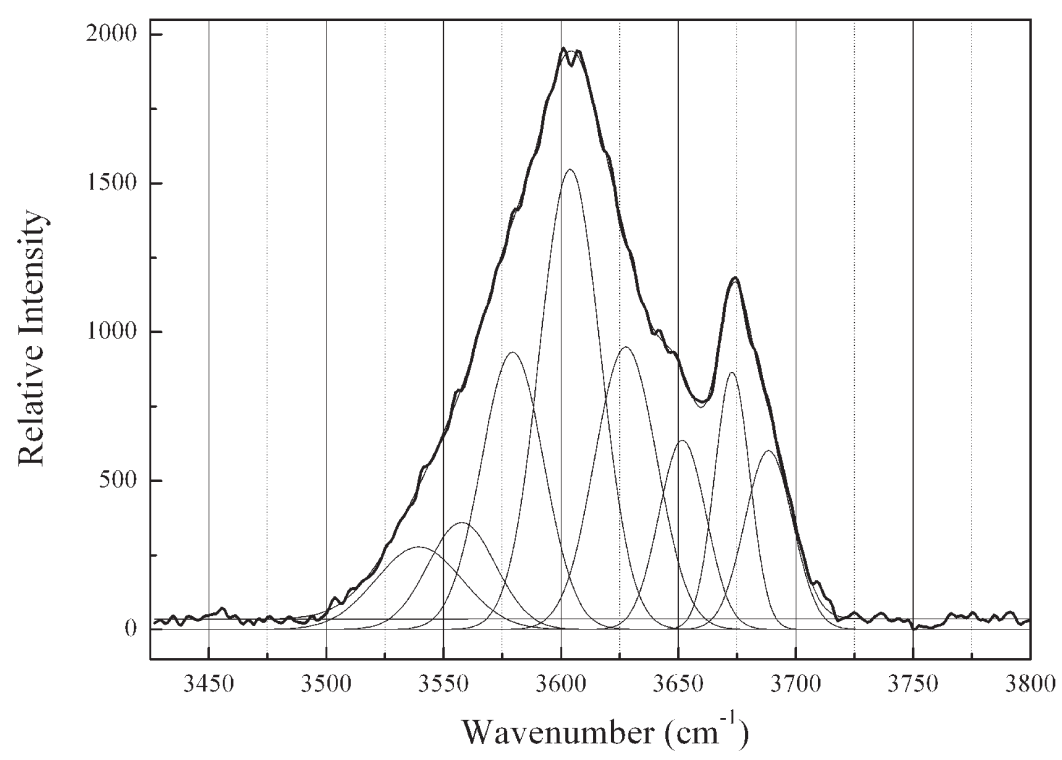

Fig. 3. Unpolarized Raman spectrum in the range $3800-3400 \mathrm{~cm}^{-1}$ of a garnet atoll

with several individual $\mathrm{OH}$ bands, the exact number is, however, difficult to determine. The Raman spectra were fitted to the smallest number of peaks (eight peaks: 3688, 3673, $3652,3628,3604,3579,3558$ and $3540 \mathrm{~cm}^{-1}$ ) required for an accurate description of the envelope band in Figure 3, the line width of individual O-H bands lies between 20 and $35 \mathrm{~cm}^{-1}$. Investigations by Kolesov and Geiger (2005) have shown that the line width of individual O-H stretching modes in the Raman spectra of hydrogrossular are broad $\left(<40 \mathrm{~cm}^{-1}\right)$ at room temperature and much narrower at low temperature ( $c a$ $2 \mathrm{~cm}^{-1}$ at $4 \mathrm{~K}$ ). Thus, Figure 3 presents only one of several models for the envelope fitting. The hydrogarnet substitution $\left(\mathrm{SiO}_{4}\right) \leftrightarrow\left(\mathrm{O}_{4} \mathrm{H}_{4}\right)$ is not the only means of incorporating $\mathrm{OH}$ in the garnet structure and the complexity of the spectra increases with increasing complexity of the garnet composition (Ambruster, Langer 1989; Rossman, Aines 1991; Amthauer, Rossman 1998; Galuskina et al. 2007b; Birkett, Trzcienski 1984). Kolesov and Geiger (2005) have shown that there are O-H modes which arise through the formation of weak hydrogen bonds $\mathrm{O}-\mathrm{H} \cdots \mathrm{O}$ within the $\mathrm{O}_{4} \mathrm{H}_{4}$ tetrahedra.

\section{ATOLL GARNET FORMATION}

Three hypotheses merit consideration in attempting to interpret the formation of atoll structure in garnets. The structure may result from the selective dissolution of internal, earlier-formed zones unstable under new conditions of mineral growth (Rast 1965; Smellie 1974; Homam 2003; Cheng et al. 2007). Alternatively, separate nucleation and growth of core and atoll may occur (Atherton, Edmunds 1966; Cooper 1972). Lastly, short-term skeletal growth of intermediate garnet zones under changing conditions of crystallization may be involved (Ushakova, Usova 1990). The last hypothesis was used 
previously by us to explain the formation of atoll hydrogarnet out of "achtarandite" pseudomorphs (Galuskina et al. 1998).

The morphology, the anatomy, the identical crystallographic orientation of all parts of the complex crystal, and the sharp contrast in composition of neighbouring zones in atoll and core, suggest that the Wiluy River atoll garnet formed as a result of the selective dissolution, and substitution by chlorite, of an unstable intermediate zone.

We propose the following model for atoll garnet formation based on our earlier work on the development of achtarandite rocks at Wiluy (Galuskina et al. 1998; Galuskin 2005). The evolution of the Wiluy deposit rocks involved a number of stages. Firstly, high-temperature, melilite Mg-skarnoids developed from xenoliths of siliceous-carbonate sediment during the magmatic evolution of the host traps. This was followed by the formation of post-magmatic Ca-skarnoids with a wiluite-grossular-wadalite paragenesis. Subsequently, mass hydration of the protoachtarandite skarnoids resulted in the formation of achtarandite rodingite-like rocks and serpentinites during regional submergence. A final hydrothermal stage was related to the late injection of dikes belonging to the trap complex (Galuskin 2005).

The evolution of the atoll garnet is linked to that of the hosting Wiluy rocks (Fig. 4). During the initial high-T skarn stage, small rhombic dodecahedral garnet crystals with complex zoning formed. Crystal growth involved the usual layered tangential mechanism. High-titanian garnet (Fig. 4, zone 1a) formed at this stage. The increased grossular component in the garnet (Fig. 4, zone II) would have been related to the development of the post-magmatic metasomatic skarnoids. During this latter stage,

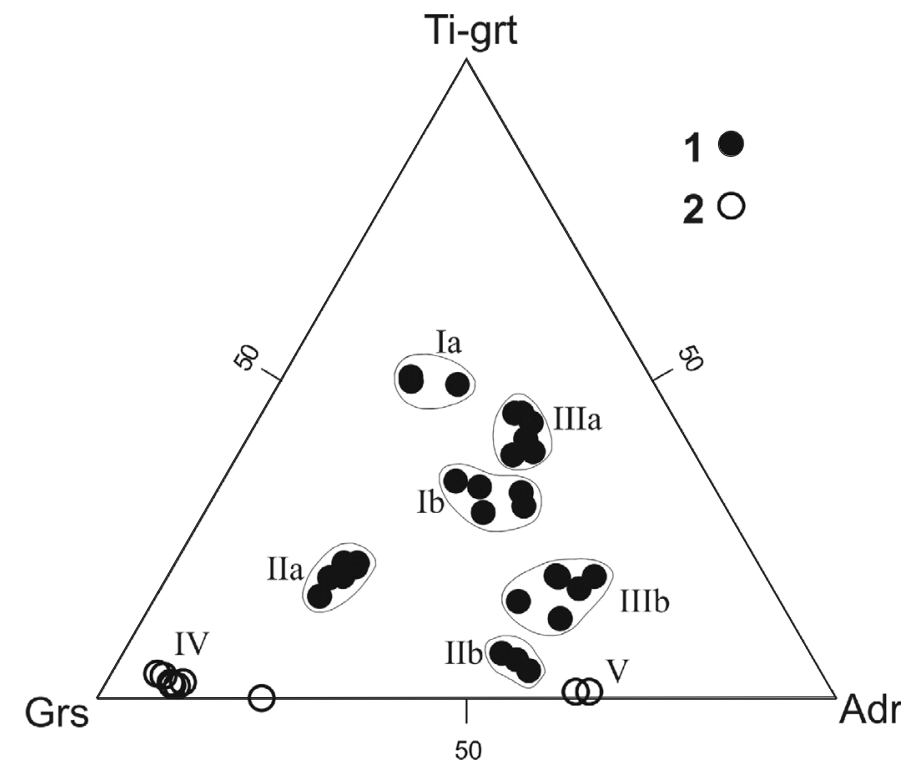

Fig. 4. Points of analyses of atoll garnets on diagram Grs - Adr - Ti-grt. I-V - sequence of atoll garnet growth zones, description in text. 1- analyses of garnet core, 2 - analyses of atoll zone.

Grs - grossular, Adr - andradite, Ti-grt - schorlomite, morimotoite 
the large crystals of grossular, wiluite and wadalite ("achtarandite") that have focussed attention on the Wiluy deposit crystallized. In rodingite-like rocks of this stage, relics of kimzeyite, scandian garnet, baghdadite and minerals of the melilite group have been identified (Galuskina et al. 2005; Galuskin et al. 2006). The last zone (III) in the core crystal, with increased $\mathrm{Fe}$, displays the typical regressive zonation of skarn garnets and the standard pattern of skarn development with decreasing temperature, increasing acidity and growing fluid volume (Korzhinsky 1982). Enrichment of zone IIIa in Zr and Ti correlates with the partial dissolution of early Ti-Zr-bearing phases in the Mg-skarn association. The key moments of change are marked by thin reaction zones $(\mathrm{Ib}, \mathrm{Ilb}$ zones, Fig. 4).

The $\{110\}$ crystals were nucleation centres for hibschite that formed as a result of the complete hydration of the primary Mg-Ca skarns - a low-temperature metasomatism in an ocean-floor setting that followed regional downwarping due to the extensive body of trap rocks above. The hibschite substituted "proto-achtarandite" (wadalite) and boron gehlenite, and formed micrometer-scale octahedral crystals in the rock groundmass and epitaxial films on large $\{211\}$ grossular crystals (Galuskin, Galuskina 2002; Galuskin 2005). The changing of the garnet form from the $\{110\}$ of the garnet core (skarn garnet) to the $\{211\}$ form of the garnet of the atoll was accompanied by the initiation of growth sectors with the columnar structure. This structure is characteristic of periods of regeneration of deformed or dissolved faces and is connected with the failure of stable, two-dimensional face growth. Columnar zones can form with most hydrated garnets up to katoite and are typical of unsteady growth conditions (Askhabov 1979). With decreasing hibschite-component supersaturation, normal face growth changed to tangential layered growth.

The dissolution of the hibschite columnar zone and its replacement by chlorite was connected with the next stage in the history of the trap rocks - regional uplift accompanying dike injection and pervasive hydrothermal alteration of the host rocks. The instability of the early hibschite zone caused by both its composition (garnet stability decreases towards katoite) and its columnar structure serves to multiply its reactive capacity greatly. Dissolution of the early hydrogarnet zone occurred simultaneously with growth of the late zone of "hydroandradite" and was connected with the increasing acidity of the mineral-forming system (Korzhinsky 1982).

Thus, the garnet-group minerals adapting to new crystallization conditions can be used to reconstruct the history of changing geological processes. The Wiluy atoll garnets reflect, in their composition and structure, the main stages in the evolution of their host rocks.

\section{REFERENCES}

AMTHAUER G., ROSSMAN G. R., 1998: The hydrous component in andradite garnet. American Mineralogist $83,835-840$.

ARMBRUSTER T., LAGER G. A., 1989: Oxygen disorder and the hydrogen position in garnet-hydrogarnet solid solutions. European Journal of Mineralogy 1, 363-369. 
ASKHABOV A.M., 1979: Regeneration of crystals. Nauka, Leningrad, 176 pp. (in Russian).

ATHERTON M.P., EDMUNDS W.M., 1966: An electron microprobe study of some zoned garnets from metamorphic rocks. Earth and Planetary Science Letters 1, 185-193.

BIRKETT T.C., TRZCIENSKI W.E.JR., 1984: Hydrogarnet, multi-site hydrogen occupancy in the garnet structure. Canadian Mineralogist 22, 4, 675-680.

CHENG H., NAKAMURA E., KOBAYASHI K., ZHOU Z., 2007: Origin of atoll garnets in eclogites and implications for the redistribution of trace elements during slab exhumation in a continental subduction zone. American Mineralogist 92, 1119-1129.

COOPER A.F., 1972: Progressive deformation of metabasic rocks from Haast Schist Group of southern New Zealand. Journal of Petrology 13, 457-492.

GALUSKIN E.V., 2005: Minerały grupy wezuwianu ze skał achtarandytowych (rzeka Wiluj, Jakucja). Szereg wiluit-wezuwian-Si-deficytowy wezuwian ("hydrowezuwian") [Minerals of the vesuvianite group from the achtarandite rocks (Wiluy River, Yakutia). Series of wiluite-vesuvianite-Si-deficient vesuvianite ("hydrovesuvianite"). Genesis of achtarandite rodingitoids. Manuscript, University of Silesia, Sosnowiec, 191 pp (In Polish with English abstract).

GALUSKIN E.V., GALUSKINA I.O., 2002: Achtarandite - sponge hibschite pseudomorph after wadalite-like phase: internal morphology and mechanism of formation. Neues Jahrbuch für Mineralogie. Abhandlungen 178, 1, 63-74.

GALUSKIN E., GALUSKINA I., WINIARSKA A., 1995: Epitaxy of achtarandite on grossular - the key to the problem of achtarandite. Neues Jahrbuch für Mineralogie. Monatshefte 7, 306-320.

GALUSKINA I., GALUSKIN E., SITARZ M., 1998: Atoll hydrogarnet and mechanism of the formation of achtarandite pseudomorphs. Neues Jahrbuch für Mineralogie. Monatshefte 2, 49-62.

GALUSKIN E., GALUSKINA I., DZIERŻANOWSKI P., 2004: New natural phase $\mathrm{MnTi}_{2} \mathrm{O}_{4}(\mathrm{OH})_{2} \times \mathrm{H}_{2} \mathrm{O}$ with uncertain structure - indicator of sea floor metasomatism. Polskie Towarzystwo Mineralogiczne - Prace Specjalne (Mineralogical Society of Poland - Special Papers) 24, 157-160.

GALUSKINA I.O., GALUSKIN E.V., DZIERŻANOWSKI P., ARMBRUSTER T., KOZANECKI M., 2005: A natural scandian garnet. American Mineralogist 90, 1688-1692.

GALUSKIN E., GALUSKINA I., DZIERŻANOWSKI P., 2006: Scandian garnet from Wiluy River, Sakha-Yakutia, Russian Federation - a potential new mineral species in the garnet group. Proceedings of the $19^{\text {th }}$ General Meeting of the International Mineralogical Association, 304. Kobe, Japan.

GALUSKINA I. O., GALUSKIN E. V., MENSHAGIN YU. V., BZOWSKA G., SEKERIN A. P., 2007a: Atoll chromspinels from serpentinites of Ospin-Kitoy massif, East Sayan. Proceedings of the International Conference "Ultrabasic-basic complexes of fold regions", 301-305. Irkutsk-Chernorud, Russia.

GALUSKINA I.O., GALUSKIN E. V., ARMBRUSTER T., PERTSEV N. N., KADIYSKI M., ZADOV A., KISLOV E. V., DZIERŻANOWSKI P., WRZALIK R., 2007b: Zr-bearing hydrogarnet in skarns with Ca-Ti-Zr-mineralization in carbonate xenolites of Dovyren massif, Nothern Pribaikalie. Proceedings of the International Conference "Ultrabasic-basic complexes of fold regions", 456-460. Irkutsk-Chernorud, Russia.

GRIGORIEV D.P., ZHABIN A.G., 1975: Onotogenesis of minerals. Nauka, Moscow, 339 pp. (in Russian).

GROAT L.A., HAWTHORNE F.C., ERCIT T.S., GRICE J.D., 1998: Wiluite,

$\mathrm{Ca}_{19}(\mathrm{Al}, \mathrm{Mg}, \mathrm{Fe}, \mathrm{Ti})_{13}(\mathrm{~B}, \mathrm{Al},[])_{5} \mathrm{Si}_{18} \mathrm{O}_{68}(\mathrm{O}, \mathrm{OH})_{10}$, a new mineral species isostructural with vesuvianite, from the Sakha Republic, Russian Federation. Canadian Mineralogist 36, 1301-1304.

HOMAM S. M., 2003: Formation of atoll garnet in the Ardara Aureole, NW Ireland. Journal of Sciences, Islamic Republic of Iran 14, 3, 247-258.

KOLESOV B.A., GEIGER C.A., 2005: The vibrational spectrum of synthetic hydrogrossular (katoite) $\mathrm{Ca}_{3} \mathrm{Al}_{2}\left(\mathrm{O}_{4} \mathrm{H}_{4}\right)_{3}$ : A low-temperature IR and Raman spectroscopic study. American Mineralogist 90, 1335-1341.

KORZHINSKY D.S., 1982: Theory of metasomatic zonality. Nauka, Moscow, 104 pp. (in Russian).

LYAKHOVICH V.V., 1952: New data for achtarandite. Doklady Akademii Nauk, 4, 625-628 (in Russian).

LYAKHOVICH V.V., 1954: New data for mineralogy of Wiluy deposit of achtarandite. Trudy Vostochno-Sibirskogo filiala Akademii Nauk SSSR, Seria Geologicheskaya 1, 85-116 (in Russian). 
OLEINIKOV B.V., 1979: Geochemistry and ore formation of platform basites. Nauka, Siberian Branch, Novosibirsk, 264 pp. (in Russian).

RAST N., 1965: Nucleation and growth of metamorphic minerals. In: Pitcher W. S. and Flinn G. W. (eds), Controls of Metamorphism. Oliver and Boyd, Edinburgh, 73-102.

ROSSMAN G.R., AINES R.D., 1991: The hydrous components in garnets: Grossular-hydrogrossular. American Mineralogist 76, 1153-1164.

SMELLIE J.A.T., 1974: Formation of atoll garnets from the aureole of the Ardara pluton, Co. Donegal, Ireland. Mineralogical Magazine 39, 878-888.

USHAKOVA E.N., USOVA L.V., 1990: Atoll garnets in a contact aureole of one of the region of the South-Eastern Tuva. Geologia i Geofizika 4, 50-59 (in Russian).

ŻABIŃSKI W., 1965a: Studium minerałów grupy hydrogranatu. (A study of minerals of the hydrogarnet group). Zeszyty Naukowe AGH 102, Rozprawy 38, 92 pp. (In Polish).

ŻABIŃSKI W., 1965b: Hydrogarnets. Prace Mineralogiczne 3, Komisja Nauk Mineralogicznych O/PAN w Krakowie, 69 pp., Kraków.

Irina GALUSKINA, Evgeny GALUSKIN, Roman WŁODYKA, Piotr DZIERŻANOWSKI, Roman WRZALIK

\section{Granaty atolowe w serpentynitach "achtarandytowych": morfologia, skład i sposób występowania}

\section{Streszczenie}

Granaty atolowe z aposkarnowych serpentynitów znad rzeki Wiluj (Republika Sacha-Jakucja, Rosja), mają klasyczną budowę, obejmującą jądro zbudowane z granatu, strefe pośrednią zbudowaną z hydrogranatu. Strefa wewnętrzna (jądro) opisanej próbki wykazuje kompleksową budowę strefowa, a granaty mają skład ewoluujący od schorlomitu do grossularu-andradytu. Granaty te są wykształcone jako dwunastościany rombowe. Granaty budujące strefę atolową wykrystalizowały jako dwudziestoczterościany deltoidowe z podrzędnie rozwiniętymi ścianami dwunastościanu rombowego i składają się z hibschytu i „hydroandradytu”. Powstanie granatów atolowych odzwierciedla główne stadia rozwoju skał stanowiska wilujskiego. Granaty te występują w obrębie metasomatycznie zmienionych, krzemionkowo-węglanowych skał ordowickich, które jako ksenolit gigantycznych rozmiarów zostały zamknięte wewnątrz wielkiej, gabrowo-dolerytowej intruzji wieku triasowego, związanej z powstawaniem trapów syberyjskich. Granaty atolowe utworzyły się w wyniku selektywnego rozpuszczania hibschytu o budowie kolumnowej, który stał się niestabilny w nowych warunkach i został zastąpiony przez chloryt. 
